\title{
PEMBERDAYAAN KOLEGIALITAS GURU DALAM PEMBENTUKAN KEMANDIRIAN ANAK BERKEBUTUHAN KHUSUS PADA UNIT SPECIAL NEEDS SEKOLAH PASO JAKARTA
}

\author{
Parwietha Sari
}

Hotmaulina Sihotang

hotmaulina.sihotang@uki.ac.id

Bintang Simbolon

bintangsmbln@yahoo.com

\begin{abstract}
Abstrak
Penelitian ini dilakukan untuk melihat upaya pemberdayaan, kendala dan strategi kolegialitas guru pada unit Special Needs terhadap pembentukan kemandirian ABK dalam keterampilan merawat diri, berkomunikasi dan bersosialisasi. Observasi di lokasi penelitian dan wawancara pada 5 guru, 1 kepala sekolah dan 4 orang tua menunjukkan bahwa dedikasi, kompetensi, kemampuan berkomunikasi dan membina relasi sosial menjadi faktor internal guru yang memengaruhi dan menjadi kendala dalam pemberdayaan kolegialitas guru di unit SN. Guna menangani hal tersebut, pimpinan sekolah melakukan strategi berupa terlibat langsung dan menjadi contoh dalam membangun relasi pertolongan, membangun komunikasi dan pemecahan masalah yang berkaitan dengan penanganan ABK. Selain itu strategi juga dilakukan dengan memfasilitasi lingkungan kerja melalui berbagai kegiatan yang mendukung pemberdayaan kolegialitas guru, seperti: memberi kesempatan mengajar, berorganisasi dan bersosialisasi secara tim. Semua strategi tersebut bertujuan memberikan pemahaman bagi guru akan pentingnya bekerjasama secara tim, memiliki soliditas, dan mengetahui karakter satu sama lain sehingga mampu berpikiran dan bersikap terbuka.
\end{abstract}

Kata kunci: kolegialitas guru, Anak Berkebutuhan Khusus (ABK). 


\begin{abstract}
The research is aimed at showing the effort, obstacle and strategy in empowering teacher collegiality in Special Needs unit within the independency of student with special needs in self care and social-communication skills. Based on the observation and interview to 5 teachers, 1 School Head and 4 parents, it shows that dedication, competency, communication and social relationship with peers become the influence and obstacle in empowering teacher collegiality. Some strategies such as: uses the School Head as a role model (in building mutual help relationship, develope communication, and solve problem with handling students), facilitate work environment with activities which support the empowerment of teacher collegiality and gives teacher more opportunities to work in team, have been used to empower teacher collegiality in this unit. Those strategies are used to build awareness and understanding about the importance of teamwork, solidity, and knowing each character to build open minded teacher.
\end{abstract}

Keywords: teacher collegiality, student with special needs 


\section{A. PENDAHULUAN}

Dalam rangka mewujudkan pelayanan publik yang adil dan makmur, UndangUndang Nomor 25 tahun 2009 tentang Pelayanan Publik pasal 29 menjelaskan bahwa penyelenggaraan pelayanan publik berkewajiban memberikan pelayanan dengan perlakuan khusus kepada anggota masyarakat tertentu sesuai dengan peraturan perundang-undangan. Hal tersebut menjelaskan bahwa semua anak - termasuk Anak Berkebutuhan Khusus (ABK) memiliki hak yang sama untuk memperoleh pelayanan pendidikan tanpa adanya pembedaan dari latar belakang kemampuan atau kondisi fisik seseorang. Sehingga kebutuhan akan pendidikan adalah milik semua orang, tidak terkecuali ABK. Pendidikan bagi ABK merupakan salah satu cara untuk mengembangkan potensi dirinya agar lebih maju dan mandiri. Kesempatan mengenyam pendidikan bagi ABK tidak mudah karena kondisinya berbeda dibandingkan peserta didik yang lain. Keterbatasan ABK memerlukan layanan pendidikan yang tepat, sesuai dengan kebutuhan dan karakteristiknya. Salah satu layanan pendidikan bagi ABK adalah program inklusi.

Guna menyelenggarakan prgram inklusi, dibutuhkan guru guru yang memiliki keterampilan dan kreatifitas tinggi terutama dalam membentuk kemandirian pada siswanya. Untuk itu perlu adanya upaya untuk memberdayakan potensi guru. Salah satu jenis pemberdayaan guru adalah secara kolegialitas yang akan di bahas dan di analisa dalam penelitian ini. Guru merupakan komponen terpenting dalam upaya pemberdayaan dibidang pendidikan, karena merupakan salah satu pilar yang memiliki peran sentral dan strategis dalam menentukan kualitas pendidikan, media transfer ilmu pengetahuan kepada peserta didik dan merupakan pihak yang paling aktif berinteraksi dengan peserta didik. Dengan demikian, maka eksistensi dan posisi guru sangatlah penting dan strategis dalam proses pendidikan dan pembelajaran. Hal ini mengisyaratkan bahwa pemberdayaan kolegialitas guru menjadi sangat penting dalam kegiatan pembelajaran di sekolah. Namun, secara realitas, masih banyak guru sebagai pelaku utama dalam proses pembelajaran yang belum diberdayakan secara kolegialitas. Hal tersebut tampak dari kurang optimalnya upaya pimpinan sekolah dalam memberdayakan guru secara kolegialitas, khususnya dalam Unit Special Needs Sekolah Paso Jakarta yang selama ini menangani siswa ABK. Hal tersebut dapat diidentifikasi melalui; (1)pemberdayaan kolegialitas guru dalam pembentukan kemandirian anak berkebutuhan khusus belum optimal sehingga untuk mewujudkan kualitas pendidikan anak berkebutuhan khusus yang tinggi masih belum tercapai, (2)ada sejumlah faktor yang membuat pemberdayaan kolegialitas guru dalam pembentukan kemandirian anak berkebutuhan khusus kurang kondusif bagi proses pembelajaran, (3)masih adanya kendala- kendala penting yang menghambat pengembangan pemberdayaan kolegialitas guru dalam pembentukan kemandirian anak berkebutuhan khusus, (4)kurangnya gagasan/ide-ide baru untuk meningkatkan efektivitas pembelajaran bagi anak berkebutuhan khusus, (5)kurang optimalnya dedikasi yang dimiliki guru dalam mengembangkan model pembelajaran bagi anak berkebutuhan khusus. 
Penelitian ini dilakukan guna menjawab berbagai permasalahan diatas. Dalam melakukan penelitian ini, peneliti membagi permasalahan pada 4 pertanyaan, yaitu; (1)bagaimana pemberdayaan kolegialitas guru dalam pembentukan kemandirian anak berkebutuhan khusus dalam merawat diri, berkomunikasi dan bersosialisasi, (2)faktor-faktor apa yang memengaruhi pemberdayaan kolegialitas guru dalam pembentukan kemandirian anak berkebutuhan khusus dalam merawat diri, berkomunikasi dan bersosialisasi, (3)kendala-kendala apa yang menghambat pemberdayaan kolegialitas guru dalam pembentukan kemandirian anak berkebutuhan khusus dalam merawat diri, berkomunikasi dan bersosialisasi, serta (4) strategi pemberdayaan kolegialitas guru.

Penelitian ini bertujuan untuk memberikan manfaat baik secara praktis maupun teoritis bagi unit Special Needs Sekolah Paso Jakarta, terutama untuk membangun pemberdayaan kolegialitas guru dalam pembentukan kemandirian anak berkebutuhan khusus yang lebih baik dalam meningkatkan kualitas pendidikan anak berkebutuhan khusus. Secara teoritis, penelitian ini digunakan untuk (a)menambah wawasan keilmuan di bidang administrasi/ manajemen pendidikan, khususnya dalam bidang pemberdayaan kolegialitas guru dalam pembentukan kemandirian anak berkebutuhan khusus serta dapat memperkaya kasanah penelitian dalam bidang administrasi/manajemen pendidikan; dan (b)berguna bagi pengembangan ilmu pengetahuan, khususnya ilmu administrasi/manajemen pendidikan.

\section{B. METODE PENELITIAN}

Penelitian yang berlokasi di unit SN sekolah Paso Jakarta ini dilakukan untuk mengetahui dan menganalisis pemberdayaan kolegialitas guru terhadap kemandirian ABK serta faktor faktor dan kendala kendala yang mempengaruhi pemberdayaan kolegialitas. Penelitian kualitatif ini menggunakan metode deskriptif dan bersifat studi kasus. Penelitian yang memiliki paradigma naturalistik ini menggunakan tehnik pengumpulan data berupa.

\section{HASIL PEMBAHASAN}

Pemerintah memiliki tanggung jawab untuk menyediakan layanan pendidikan bagi seluruh masyarakat, termasuk Anak Berkebutuhan Khusus (ABK). Untuk memfasilitasi kebutuhan ABK, pemerintah menyelenggarakan program pendidikan inklusi. Sekolah Paso Jakarta merupakan salah satu dari sekian banyak sekolah khususnya di Jakarta yang mengadakan program pendidikan inklusi. Unit Special Needs (SN) adalah satu dari 4 unit dibawah naungan departemen Special Education (S.E) yang menangani ABK di usia dini. Agar program inklusi dapat berjalan lancar, maka masing masing guru di unit SN dituntut untuk memiliki kemampuan mengembangkan ide ide kreatif, berani tampil beda, mengembangkan potensi diri, dan mandiri saat menyampaikan materi ajar pada siswanya. Berkaitan dengan hal tersebut, maka unit SN melakukan upaya pemberdayaan kolegialitas guru guna meningkatkan kinerja dan performa guru.

Pemberdayaan, didefinisikan sebagai suatu proses meningkatkan perasaan atas keyakinan pada kemampuan diri antara anggota organisasi melalui identifikasi kondisi ketidakberdayaan dan lalu menghapuskan ketidakberdayaan itu 
melalui praktik organisasi formal dan teknik informal yang menyediakan informasi yang meyakinkan atas kemampuan diri (Conger dan Kanungo, dalam Ivancevich, Konopaske, dan Matteson, 2014:343). Sedangkan, Jarzabkowski (dalam Shah,2012:131) menjelaskan bahwa kolegialitas merupakan keterlibatan guru untuk berinteraksi dengan rekan rekan mereka pada tingkat apapun, baik itu intelektual, moral, politik, sosial, dan/atau emosional secara profesional dan sosial/emosional ditempat kerja. Pemberdayaan kolegialitas guru di lingkungan sekolah memberikan beberapa keuntungan, yaitu: meningkatkan (1) pertumbuhan profesionalitas dan pengembangan guru, (2) profesionalisme guru, (3) kualitas sekolah dan efektivitas organisasi, dan (4) sikap, perilaku dan pencapaian siswa (Shah, 2012:1242). Mengacu pada keuntungan kolegialitas tersebut, khususnya dalam meningkatkan sikap, perilaku dan pencapaian siswa, maka penelitian ini bertujuan untuk menganalisa dampak pemberdayaan kolegialitas guru pada pembentukan kemandirian ABK, khususnya dalam merawat diri, berkomunikasi dan bersosialisasi.

\section{a. Faktor faktor yang Memengaruhi Pemberdayaan Kolegialitas Guru}

Dalam melakukan upaya pemberdayaan, Foy (dalam Sumaryadi, 2005:113) melihat empat unsur utama yang saling mengkait satu dengan yang lainnya, yaitu: (1) pemberdayaan terfokus pada kinerja (perfomance fokus), (2) real teams -kinerja team yang baik berasal dari team yang baik, (3) pemberdayaan amat butuh visible leadership, (4) pemberdayaan membutuhkan komunikasi yang baik (good communication). Berkaitan dengan hal tersebut maka faktor internal guru menjadi salah satu faktor utama, selain faktor eksternal yang memengaruhi pemberdayaan kolegialitas guru dalam pembentukan kemandirian ABK. Faktor internal guru yang dimaksud adalah dedikasi, kompetensi keterampilan, kemampuan berkomunikasi dan membina relasi sosial dengan rekan kerja. Hasil penelitian menunjukkan bahwa:

\section{Dedikasi}

Dedikasi guru sangat berpengaruh dalam hal pembentukan kemandirian ABK. Guru yang memiliki dedikasi tinggi/potensial dapat menjadi contoh (lead by example) bagi guru- guru yang lain. Hal ini sangat mempengaruhi pemberdayaan kolegialitas. Para guru yang memiliki dedikasi tinggi/potensial mau meluangkan waktu, tenaga, pikiran, perasaan, mengoptimalkan upaya yang dilakukan, dan berkreativitas serta mau berkolaborasi dalam hal bekerjasama dengan rekan-rekannya dalam penyusunan program, pencapaian pembelajaran, menggunakan berbagai metode/cara dan strategi saat menyampaikan materi ajar yang sesuai dengan kemampuan siswa, serta teknik yang cukup optimal dalam pengajarannya. Selain itu juga menciptakan lingkungan yang mendukung agar siswa memiliki kesempatan lebih besar dalam rangka membentuk kemandirian ABK. Faktor dedikasi tersebut terlihat dalam mengajarkan ABK merawat diri, berkomunikasi, dan bersosialisasi.

\section{Kompetensi Keterampilan}

Faktor kompetensi (keterampilan) yang dimiliki para guru sangat 
berpengaruh dalam pembentukan kemandirian ABK. Bagi para guru yang memiliki kompetensi (keterampilan) tinggi dapat menjadi contoh. Teknik-teknik pengajaran yang benar dan mempengaruhi cara mengajarnya sangat berpengaruh terhadap pemberdayaan kolegialitas di antara para guru. Selain itu para guru mau bekerjasama dengan rekannya guna menampilkan keativitasnya dalam menyampaikan materi ajar bagi siswanya, serta memiliki keterampilan yang lebih up to date dan beragam dalam mengajar, yang diperoleh tidak hanya melalui workshop/seminar, membaca buku-buku acuan, tetapi juga diperoleh melalui rekan-rekannya. Para guru yang bekerja dalam tim (baik ketika formal sedang mengajar, maupun di luar jam mengajar) tidak segan berbagi informasi dan tidak ragu berbagi keterampilan yang dimilikinya pada rekan lainnya, sehingga guru yang terampil berperan sebagai mentor atau coach bagi para guru baru atau yang belum begitu terampil.

\section{Kemampuan Berkomunikasi}

Faktor kemampuan berkomunikasi sangat menentukan pemberdayaan kolegialitas guru. Guru yang memiliki potensi kemampuan berkomunikasi yang baik dengan rekan-rekannya dapat mempengaruhi pemberdayaan kolegialitas dalam membentuk kemandirian ABK, mampu menggunakan cara berkomunikasi yang mudah dipahami (menggunakan kata-kata singkat, padat, jelas, informatif, dan langsung pada inti permasalahannya), sehingga rekannya mengetahui dengan pasti apa yang dimaksudkan oleh guru tersebut. Selain itu juga mampu menginformasikan dan mengkomunikasikan tujuan dan target pencapaian/strategi yang diharapkan serta dibutuhkan siswa. Saat menyebarkan informasi, guru mampu menggunakan bahasa dan cara penyampaian yang baik agar mudah dipahami oleh penerima informasi.

\section{Membina Relasi Sosial.}

Faktor relasi sosial sangat berpengaruh. Bagi para guru yang berpotensi memiliki relasi sosial yang baik dengan rekan-rekannya (seperti memiliki sikap tenggang rasa, sigap saat dibutuhkan bantuannya, memberikan dukungan positif pada rekan-rekannya) mampu bekerjasama dan berkolaborasi dengan rekannya secara baik. Selain itu guru tersebut tidak merasa sungkan dan mudah meminta bantuan saran, pemikiran maupun fisik, baik untuk bekerjasama dalam proses belajar mengajar atau mengajarkan sesuatu kepada ABK hingga pencapaian hasil yang optimal maupun di saat menggantikan tugasnya ketika melakukan tugas lain dalam waktu yang bersamaan. Relasi sosial di antara guru yang terjalin dengan baik dan kondusif mempengaruhi bagaimana para guru berinteraksi satu sama lain serta berupaya untuk berdialog dalam membicarakan program-program, kemajuan, dan juga intervensi yang sedang/perlu dilakukan dalam mempercepat proses pembelajaran dan membentuk kemandirian ABK. Sedangkan faktor faktor yang dapat menjadi penghambat 
pemberdayaan kolegialitas guru, menurut Covey (2005:380) adalah keberhasilan organisasi dalam memberdayakan dan mengembangkan kompetensi karyawannya agar menjadi lebih profesional dalam menyelesaikan pekerjaannya dipengaruhi oleh beberapa faktor penghambat, yaitu: (1) pimpinan takut membiarkan proses berjalan, (2) sistem tidak selaras, (3) pimpinan tidak mempunyai kemampuan, (4) karyawan tidak mempunyai kemampuan, (5) karyawan tidak menginginkan tanggung jawab, (6) pimpinan terlalu sibuk, (7) manajemen terlalu mengontrol, (8) tidak ada visi perusahaan, (9) karyawan tidak percaya pada pimpinan, dan (10) karyawan tidak punya integritas. Kendala-kendala yang Menghambat Pemberdayaan Kolegialitas Guru dalam Pembentukan Kemandirian ABK.

\section{Dedikasi}

Hasil penelitian ini menunjukkan kurang terlihat adanya dedikasi yang tinggi, karena guru hanya melakukan pekerjaan sebagai rutinitas semata, bahkan tidak optimal dalam melakukan pekerjaa. Tetapi sebenarnya dedikasi guru tetap terlihat pada saat mengajarkan kemandirian ABK walaupun tidak memiliki kemampuan untuk membina hubungan yang baik dengan rekan-rekannya. Dedikasi tersebut dapat menjadi lebih baik jika disertai dengan sudut pandang lain dari rekan-rekannya. Misalnya: saat mengajarkan kegiatan cuci tangan pada ABK guru memperlihatkan dedikasinya dengan terus membantu siswanya, padahal dari sudut pandang rekannya siswa tersebut mampu melakukan kegiatan tersebut secara mandiri. Sebagai akibatnya, perkembangan siswa dalam merawat diri pun menjadi tidak maksimal dan tidak mencapai tujuannya.

\section{Kompetensi Keterampilan}

Hasil temuan penelitian ini menunjukkan bahwa kompetensi keterampilan yang dimiliki oleh guru tidak cukup baik, tidak potensial, padahal hal tersebut sangat penting dan diperlukan dalam hal merawat diri, berkomunikasi, serta bersosialisasi pada pembentukan kemandirian ABK. Hal ini dapat menjadi salah satu penghambat dalam mendukung pemberdayaan kolegialitas. Terlebih bila para guru yang memiliki keterampilan minim dan tidak mumpuni tidak mau menerima masukan atau pelajaran dari rekan-rekan satu tim kerja. Jelas ini merupakan hambatan.

\section{Membina Relasi Sosial}

Temuan penelitian ini menunjukkan bahwa membina relasi sosial dalam memengaruhi kolegialitas guru dalam pembentukan kemandirian $\mathrm{ABK}$ dalam hal merawat diri, berkomunikasi dan bersosialisasi kurang terjalin dengan baik. Hal itu terlihat dengan adanya guru yang tidak bisa menjalin kerjasama dengan rekanrekannya, bahkan cenderung menutup diri, sehingga tidak mampu membina relasi sosial yang baik di lingkungan kerjanya. Keadaan ini membuat sulit antara guru dan rekan-rekannya ketika saling 
membutuhkan pertolongan atau bantuan disaat melakukan proses belajar mengajar dalam membentuk kemandirian ABK, baik dalam hal merawat diri, berkomunikasi, maupun bersosialisasi. Selain itu guru dapat ketinggalan informasi terkini atau aktual yang berkaitan dengan langkah-langkah atau metode mengembangkan siswa ABK merawat diri, berkomunikasi, dan bersosialisasi. Relasi sosial yang tidak baik juga dapat menyebabkan guru dan rekan- rekannya tidak dapat menyampaikan apa yang seharusnya disampaikan.

\section{Kemampuan Berkomunikasi}

Temuan penelitian ini menunjukkan bahwa kemampuan berkomunikasi kurang baik, tidak memiliki potensi berkomunikasi, dan cenderung memiliki masalah dalam berkomunikasi, sehingga menimbulkan suasana kerja yang tidak kondusif. Dengan tidak baiknya kemampuan berkomunikasi para guru dikhawatirkan aktivitas yang terencana dapat terhambat. Bahkan komunikasi di antara para guru tersebut tidak tercipta/terjadi. Sementara pemberdayaan kolegialitas guru untuk membantu dalam mengembangkan pembentukan kemandirian $\mathrm{ABK}$ dalam merawat diri, berkomunikasi, dan bersosialisasi membutuhkan interaksi melalui diskusi antar guru/tim guru. Ketika kemampuan berkomunikasi di antara guru tidak tercipta atau terkondisikan dengan baik, maka arus informasi pun tidak dapat mengalir dengan baik, karena adanya rintangan sesama guru sulit mengondusifkan komunikasi.

\section{b. Strategi Pemberdayaan Kolegialitas Guru}

Beberapa indikator yang dapat dijadikan ukuran dalam pemberdayaan kolegialitas, yaitu: (1) membangun relasi pertolongan; (2) membangun komunikasi; (3) terlibat dalam pemecahan masalah dan merefleksikan sikap; dan (4) nilai profesional pekerjaan social (Suharto, 2005: 68). Dengan mengacu pada indikator tersebut, pimpinan sekolah telah melakukan beberapa upaya, yaitu:

\section{Membangun Relasi Pertolongan}

Dalam hal ini, pimpinan sekolah membangun semangat saling menolong diantara guru dengan cara menciptakan aktivitas atau event tahunan di sekolah. Cara ini dilakukan agar para guru dapat berkolaborasi lebih jauh untuk kemudian dapat belajar dan mengenal karakter satu sama lain. Selain itu dalam rapat-rapat yang diselenggarakan di sekolah pesan yang disampaikan agar para guru saling bertanya, berdialog, tolong menolong pada rekan kerja antar guru lintas unit yang dirasa perlu. Kemudian dalam umpan balik (feedback) guru tiap tahunnya tak jarang juga diberikan saran, pengarahan, pelatihan dan penguatan pada guru- guru tertentu, baik guru senior berpengalaman maupun guru yunior yang belum berpengalaman tentang kerja tim (team work), dan menyampaikan pesannya agar saling terbuka, tidak ragu bertanya, tolong menolong atau meminta tolong, recheck, memastikan hal tertentu, konsultasi, atau apapun dengan sesama rekan kerja khususnya dalam memberikan 
materi ajar dan penggunaan strategi tertentu dalam mengajar ABK. Selanjutnya pimpinan sekolah juga menempatkan diri sebagai model dan memberikan contoh nyata yang dapat ditiru para guru dengan cara turun tangan langsung membantu para guru yang memerlukan bantuan dalam kunjungan berkalanya ke unit $\mathrm{SN}$, misalnya dalam penanganan ABK yang sedang tantrum atau melakukan back up di saat unit SN kekurangan guru.

\section{Membangun Komunikasi}

Dalam membangun komunikasi antar guru, pimpinan sekolah memberikan saran dan pengarahan (verbal) secara berkala kepada sesama guru untuk saling berkomunikasi. Beberapa keputusan yang diambil oleh pimpinan sekolah merupakan hasil pendapat guru dan masukan yang diperoleh setelah berdiskusi dengan koordinator unit. Sejalan dengan hal itu, pimpinan sekolah meminta pada koordinator untuk rutin membuat rapat koordinasi internal antar unit, sehingga segala hal dapat dibicarakan, didiskusikan, dan diselesaikan. Dalam membangun komunikasi antar guru juga dilakukan berbagai macam aktivitas seperti halnya: diskusi/sharing session secara berkelompok guna memberi kesempatan para guru untuk berani melontarkan pendapat, bertanya, memberi saran kepada satu sama lain. Saat melaksanakan assesment dan pembuatan PPI (Program Pembelajaran Individual) pada masing masing $\mathrm{ABK}$, guru juga diberikan kesempatan berdiskusi dan bertukar pendapat pada rekan rekannya baik dalam satu unit atau antar unit. Upaya yang tidak kalah pentingnya adalah dengan membuat whatsapp group yang berfungsi sebagai alat koordinasi baik antar guru maupun antar koordinator. Semua upaya tersebut dilakukan meningkatkan dan mempermudah para guru dari unit yang berbeda agar dapat saling bekerjasama dan berkomunikasi, sehingga bagi guru yang belum berpengalaman dan masih menemui kendala dalam menentukan langkah pengajaran untuk pengajaran pada $\mathrm{ABK}$ dapat teratasi.

\section{Terlibat dalam Pemecahan Masalah}

Pimpinan sekolah turut terlibat dalam memecahkan masalah yang berkaitan dengan penanganan $\mathrm{ABK}$ dengan cara memberikan pandangan, saran, solusi, baik secara formal maupun informal disaat para guru menghadapi permasalahan yang dihadapi dalam menangani ABK. Selain itu, ia juga memberikan kepercayaan secara penuh kepada para guru dalam menangani murid-muridnya, dimana koordinasi dan pengawasan langsungnya ada pada koordinator unit. Semua permasalahan yang dihadapi setiap harinya terlebih dahulu diselesaikan oleh para guru karena para guru memiliki tanggungjawab dengan perhitungan bahwa semua perilaku dan tugasnya harus diselesaikan. Apabila permasalahan keseharian yang dihadapi oleh para guru tidak terselesaikan, maka guru dapat berkoordinasi dengan koordinatornya. Begitupula bila koordinasi yang dilakukan beserta koordinator tidak menyelesaikan permasalahan juga, maka pimpinan 
sekolah atau kepala sekolah ikut dilibatkan. Untuk mendukung keterlibatan antar guru dalam memecahkan berbagai persoalan diupayakan melalui sejumlah aktivitas yang dilakukan secara formal, seperti kegiatan sharing session, induction untuk meningkatkan performa para guru dan mendidiknya supaya lebih rajin lagi membaca buku-buku panduan terutama yang berkaitan dengan pemecahan masalah ABK. Semua itu dilakukan agar para guru memiliki pengetahuan untuk memecahkan berbagai permasalahan ABK.

Indikator indikator tersebut sesuai dengan upaya pemberdayaan kolegialitas yang sedang dilakukan di lingkungan kerja unit SN yang mendukung kerjasama guru secara team. Selain itu diperlukan satu formulasi strategi agar upaya pemberdayaan kolegialitas menjadi optimal dan kendala kendala yang muncul dapat diminimalisir, yaitu dengan cara: pertama, memfasilitasi lingkungan kerja dengan berbagai kegiatan yang dapat mendukung pemberdayaan kolegialitas guru, misalnya: mengadakan kegiatan teacher gathering setahun 2 kali, merayakan ulang tahun guru bersama rekan-rekannya, mengunjungi rekan yang sakit atau melahirkan bersama rekan-rekan, menyelenggarakan waktu santai sebelum dan sesudah jam mengajar setidaknya selama 15-20 menit agar para guru berkesempatan untuk bersosialisasi dengn rekan-rekannya, merayakan hari guru bersamasesama rekan guru, rutinitas berkumpul sebelum atau sesudah kegiatan mengajar di mulai atau berakhir. Kedua, kepala sekolah sebagai koordinator para guru memberikan contoh atau bersikap sebagai model secara langsung pada guru untuk menunjukkan hubungan kolegialitas yang diharapkan, dengan cara: menunjukkan sikap terbuka dan bersedia memberikan saran saat guru membutuhkan petunjuk, bimbingan, atau melakukan pengajaran pada $\mathrm{ABK}$, memberikan contoh langsung pada guru dalam menangani ABK dalam kondisi yang sesungguhnya saat melakukan observasi di unit, menunjukkan sikap terbuka namun tetap menghormati satu sama lain saat bersosialisasi dengan guru sehingga tidak canggung saat meminta bantuan. Ketiga, membentuk tim mengajar dengan dalih bahwa siswa tidak menjadi obyek pengawasan dan tanggung jawab salah satu guru saja sepanjang tahun. Dengan system seperti itu antara guru yunior yang belum terampil dapat dibantu guru senior, kerjasama dapat dilakukan dengan cara mentoring. Artinya, guru yunior dimentori dan dibimbing oleh guru senior. Keempat, setiap guru hendaknya diberikan kesempatan untuk bertanggung jawab atas suatu program, baik itu program inti maupun program ekstra. Ketika seseorang pernah merasakan baik menjadi leader (meskipun lingkup kecil) atau jadi follower, biasanya lebih mampu berempati dan mau melakukan sesuatu untuk keberhasilan bersama, karena pernah merasakan di posisi manapun.

\section{KESIMPULAN, IMPLIKASI, DAN SARAN \\ 1. Kesimpulan}

Pertama, pemberdayaan kolegialitas guru dalam pembentukan 
kemandirian ABK pada Unit Special Needs Sekolah Paso Jakarta yang dilakukan pimpinan sekolah dalam membangun semangat kebersamaan diantara para guru untuk saling menolong cukup baik. Pimpinan sekolah tidak hanya memberikan saran, pengarahan, pelatihan, dan penguatan pada guru-guru tertentu baik guru senior maupun yunior berkaitan dengan kerja tim (team work), melainkan juga memberikan pesan agar para guru saling terbuka, tidak ragu saling bertanya, berdialog, tolong menolong atau meminta tolong pada rekan kerja antar guru lintas unit yang dirasa perlu, recheck, memastikan hal tertentu, konsultasi, atau apapun dengan sesama rekan kerja khususnya dalam memberikan materi ajar dan penggunaan strategi tertentu dalam mengajar ABK. Pimpinan sekolah juga membangun komunikasi diantara para guru melalui saran dan pengarahan (verbal) secara berkala kepada sesama guru untuk saling berkomunikasi. Pimpinan sekolah bahkan terlibat dalam pemecahan berbagai persoalan yang dihadapi para guru berkaitan dengan penanganan ABK dengan cara memberikan pandangan, saran, solusi, baik secara formal maupun informal.

Kedua, faktor-faktor yang memengaruhi pemberdayaan kolegialitas guru dalam pembentukan kemandirian ABK pada Unit Special Needs Sekolah Paso Jakarta adalah faktor internal guru berupa dedikasi, kompetensi (keterampilan), membina relasi sosial, dan kemampuan berkomunikasi. Keempat faktor tersebut merupakan pendukung dalam membangun pemberdayaan kolegialitas guru dalam membentuk kemandirian ABK dalam hal merawat diri, berkomunikasi, dan bersosialisasi.

Ketiga, kendala-kendala yang menghambat pemberdayaan kolegialitas guru dalam pembentukan kemandirian $\mathrm{ABK}$ adalah kondisi internal guru seperti: dedikasi, kompetensi (keterampilan), membina relasi sosial, dan kemampuan berkomunikasi. Keempat kendala tersebut berkaitan dalam pembentukan kemandirian $\mathrm{ABK}$ dalam hal merawat diri, berkomunikasi, dan bersosialisasi. Dedikasi guru masih relatif rendah, kompetensi (keterampilan) guru tidak cukup baik/memadai, aktivitas membina relasi sosial guru tidak terjalin dengan baik, dan kemampuan berkomunikasi guru juga tidak baik/memadai.

Keempat, strategi pemberdayaan kolegialitas guru pada Unit Special Needs Sekolah Paso Jakarta yang lebih efektif dalam membantu pembentukan kemandirian $\mathrm{ABK}$ adalah (1) strategi pemahaman yang luas bagi guru untuk sadar melakukan aktivitas secara bekerjasama atau bekerja secara tim (team work), berpasangan secara bergantian sesama guru agar terbiasa, memiliki soliditas/kekompakkan, dan mengetahui karakter satu sama lainnya; (2) menyetting cara kerja agar guru-guru terekspose lebih dalam bekerja secara tim bersama rekan-rekannya sesering mungkin saat mengajar siswa di kelas, lingkungan sekolah, dan di ruang publik; (3) mengadakan kegiatan yang menyenangkan secara kebersamaan seperti: berkumpul selama 15 menit sambil makan bersama, karaoke, nonton bersama, kegiatan year end excursion, sleepover, atau year end party, dan lain-lain; (4) mengadakan berbagai training atau seminar yang dapat memperkaya pengetahuan dan meningkatkan keterampilan para guru dalam mengajar ABK; dan (5) memotivasi guru 
dengan memberikan apresiasi pada masing-masing guru dengan cara bervariasi, misalnya dengan memberikan insentif berupa kenaikan gaji atau bonus, penghargaan (piagam), peningkatan jabatan dan lain-lain.

\section{Implikasi}

Saat guru terkondisikan bekerja secara individual, 4 faktor internal yaitu dedikasi, kompetensi keterampilan, kemampuan berkomunikasi dan membina relasi sosial sebenarnya tidak terlalu berpengaruh pada performa kinerja guru. Seorang guru tetap dapat menampilkan dedikasi dan keterampilannya dengan mengikuti berbagai seminar, workshop atau mencari sumber keterampilan melalui buku acuan. Kemampuan berkomunikasi dan membina relasi sosial pun tidak terlalu di perlukan. Namun karena guru di unit SN dituntut untuk bekerja secara tim ditambah dengan kondisi pekerjaan yang seringkali tidak terprediksi, maka faktor dedikasi, kompetensi (keterampilan), komunikasi dan relasi sosial dengan rekan kerja amat dibutuhkan dan berpengaruh besar dalam melihat kemampuan kinerja guru saat bekerja secara tim. Disamping itu, berbeda dengan hasil penelitian sebelumnya, penelitian ini membuktikan bahwa pemberdayaan kolegialitas guru di unit SN membutuhkan perpaduan strategi yang mengandalkan kesuka relaan dan penyettingan dalam bekerjasama antar guru.

\section{Saran}

Guna meningkatkan pemberdayaan kolegialitas di unit SN, pimpinan sekolah perlu melakukannya secara intensif agar lebih efektif guna mendukung upaya guru dalam membentuk kemandirian ABK. Dedikasi, kompetensi (keterampilan), kemampuan membina relasi sosial, dan berkomunikasi para guru pun perlu ditingkatkan terus menerus agar lebih efektif dalam menunjang kegiatan pembentukan kemandirian ABK, terutama dalam merawat diri, berkomunikasi, dan bersosialisasi. Selain itu, unit SN perlu menerapkan strategi pemberdayaan kolegialitas guru yang meliputi: strategi pemahaman pentingnya bekerjasama secara team, berganti pasangan dalam mengajar, memiliki soliditas (kekompakkan), dan mengetahui karakter satu sama lain; menyetting cara kerja guru dalam kerja tim saat mengajar di kelas, lingkungan sekolah, dan ruang publik; melakukan kegiatan menyenangkan secara bersama; dan mengikuti training/seminar untuk memperkaya pengetahuan dan keterampilan guru dalam mengajar ABK; dan memotivasi guru dengan cara memberikan apresiasi secara bervariasi dalam bentuk insentif berupa kenaikan gaji, bonus, penghargaan (piagam), peningkatan jabatan, atau lainnya. Sebagai tambahan pada saran, perlunya dilakukan penelitian lanjutan dengan pendekatan kuantitatif untuk mengetahui dan mengalisis pengaruh dedikasi, kompetensi (keterampilan), kemampuan membina relasi sosial, dan berkomunikasi guru terhadap kemandirian ABK, terutama dalam hal merawat diri, berkomunikasi, dan bersosialisasi.

\section{DAFTAR PUSTAKA}


Covey, Stephen R. (2005). The 8th Habit, Jakarta: PT. Gramedia.

Ivancevich, John M., Robert Konopaske and Michael T. Matteson. (2014). Organizational Behavior and Management, Tenth Edition, New York: Mc-Graw Hill Education.

Jarzabkowski, Lucy M., "The Social Dimensions of Teacher Collegiality," Journal of Educational Enquiry, Vol. 3, No. 2, 2002: pp. 1-20.

Shah, Madiha, "The Impact of Teachers' Collegiality on their Organizational Commitment in High- and Low-Achieving Secondary Schools in Islamabad, Pakistan," Journal of Studies in Education, Vol. 2, No. 2, (2012): pp. 130-156.

Shah, Madiha, "The Importance and Benefits of Teacher Collegiality in Schools a Literature Review," Procedia-Social and Behavioral Sciences, Vol. 46, (2012): pp. 1242-1246.

Suharto, E. (2005). Membangun Masyarakat Memberdayakan Rakyat, Bandung: PT. Refika Aditama.

Sumaryadi, I. N. (2005). Perencanaan Pembangunan Daerah Otonom dan Pemberdayaan Masyarakat, Jakarta: Citra Utama.

Undang-Undang Nomor 25 tahun 2009 pasal 29 tentang Pelayanan Publik 
Volume 8, Nomor 2, Juli 2019 